\title{
MUSEERNE SOM ARNEN FOR DET EVOLUTIONÆRE VERDENSBILLEDE
}

Ella Hoch

On pensait alors [1899] que la civilisation occidentale, enlisée dans le rationalisme et l'athéisme, avait fait son temps et allait vers son déclin. *

Mange vesterlandinge tager afstand fra den bibelske forklaring om Jorden og dens organismer, at de blev til ved en skabelse, men mener, at de opstod gennem udvikling, evolution. En livløs proto-Jord, koncentreret $i$ Solsystemet samtidigt med dets øvrige planeter for omkring 4,6 milliarder àr siden, afgav vand $i$ en hydrosfere og luft $i$ en atmosfere, og der blev liv som selvkopierende molekylstrukturer på jordoverfladen. Det foregik måke i miljøer af lighed med den moderne Jords black smokers, naturlige skorstene på oceanbunden, hvorudaf pulser hede, vandige opløsninger af grundstoffer fra de dybe bjergarter, der giver naring til anaërobe mikrober. Simpelt liv blev til mere komplekst liv, som vi kun kender til i storste mangelfuldhed, indtil de biogeokemiske forhold for en 600 millioner air siden betingede mineralsk skeletdannelse. Ydre skelet, indre skelet, afforskellige mineraler, med eller uden indlejrede organiske stoffer - efter den tid lå der hårde data tilbage mellem bjergartskornene som levn af dyr og planter til eftertidens funderinger.

Dyr undrer sig over det usedvanlige, fugle og pattedyr ikke mindst, blandt dem er mennesket. Skridtet fra forundring til forståelse og rationel rekonstruktion af processer og former kaldes naturvidenskab. I dette historisk lange, sejge skridt spiller museerne en vigtig rolle.

Ordet evolution har flere meninger. Andrej Tarkovskij, den russiske filmskaber, skrev i "Den forseglede tid" (1984): «Fra det øjeblik, Eva havde spist af æblet fra Kundskabens træ, var menneskeheden dømt til evig sandhedssøgen. .../ «I dit ansigts sved skal du æde dit brød...»/ Og således kom mennesket, "Skabningens
Øverste», til stede på Jorden og gjorde sig til herre over den. Vejen, mennesket siden har fulgt, kalder man almindeligvis evolution. Det er også den menneskelige selverkendelses kvalfulde vej".

Denne kunstens opfattelse af evolution adskiller sig fra videnskabens, her naturvidenskabens, der ser evolution som, især, 
4 det levendes udvikling fra de tidligste selvreproducerende molekyler til de mangfoldige senere, nutidige og fremtidige organismer. Der tales om fylogenetisk udvikling, det vil sige slægtsmæssig udvikling gennem plante- og dyreriget. Denne er betinget af Jordens udvikling. Den gensidige afhængighed mellem organisk og uorganisk udvikling i biosfæren påvirkes af processer i de øvrige terrestriske sfærer og fra verdensrummet, der muligvis ikke er blottet for liv; men udviklingen styres ikke af en eller flere guder. Dette er kernen i det evolutionære verdensbillede.

Videnskabens rødder sugede næring fra Asien og Afrika. Antikkens Grækenland var grobund for Europas naturvidenskab, araberne tog over i Middelalderen og værnede om den, indtil europæerne atter fattede interesse for den og kultiverede den med Renaissancens åbnede sanser. Rigdommene, der hjemførtes fra de ny verdener hinsides oceanerne, og bogtrykkerkunsten, der gav folket adgang til information, bragte os ud af skolastikkens tid og ind i videnskabens tid. Europæerne blev individer.

I sin rationelle stræben efter objektiv sandhed er naturvidenskaben ofte kollideret med kunsten:

Videnskab! Du sande datter af Gammel Tid!

Som forandrer alting ved dit granskende blik.

Hvorfor nager du digterens hjerte,

Rovfugl, hvis vinger er de farveløse realiteter?

Hvordan skulle han kunne elske dig? Og hvorledes dømme dig viis,

Som ikke ville lade ham i fred $i$ hans søgen

Efter skatte i de juvelbesatte himle,

Skønt han svævede på frygtløs vinge?

Har du ikke draget Diana ned fra hendes vogn?

Og drevet træets nymfe fra skoven
På søgen efter ly på en lykkeligere stjerne?

Har du ikke revet Najaden fra hendes flod, Alfen fra det grønne græs, og fra mig Sommerdrømmen under tamarindetræet?

Den smerte, Edgar Allan Poe udtrykte gennem sin Sonnet - Til Naturvidenskaben (1845) læser man igen ud af et moderne menneskes tanker over konsekvenserne af den forplantningsteknologiske forskning, Jørgen Steen Nielsen (1994):

På alle områder, der har med skabelsesprocessen at gøre, rykker teknologien ind og underminerer det, vi har kendt som noget naturgivent og oplevet som noget urørligt, helligt. ... Vi kan - ind imellem ikke andet end blot råbe smerten ud.

\section{DET EVOLUTIONARE VERDENSBILLEDE}

Naturvidenskaben med sin hale af teknologiske følger avancerer kometagtigt ud ad det, der af dens udøvere opfattes som virkelighedens og den objektive sandheds spor. Findes den sandhed? Troen på, at der eksisterer en absolut sandhed, som man kan bevæge sig frem imod gennem sande teorier, kan kaldes naiv realisme (Koliadin, 1994). Inden for dette filosofiske system er det videnskabens rolle at udskille rigtige ideer og teorier fra forkerte. Når den «sande» teori er fundet og anses for bevist, koncentreres alle kræfter om at videreudvikle den, mens forsøg på at udforske «forkerte» ideer er ilde sete. Herimod stiller ukraineren Vladimir Koliadin den realisme, der ikke søges gennem «sande» og "usande» ideer, men som man tilnærmer sig gennem frugtbare og ufrugtbare ideer. Videnskabshistorien viser nemlig, at mange ideer, der først blev kaldt forkerte, 
senere viste sig at indeholde væsentlige elementer af sandhed. Den hovedlære, der kan uddrages af historien, er, at ingen er i stand til umiddelbart at afgøre, hvilke ideer der er de sande. Derfor skal vort arbejde ikke bestå i at "bevise» eller "modbevise», at acceptere eller forkaste ideer. Men frem for at lade ideer udelukke hinanden - skal opmærksomheden samles om at extrahere værdifulde dele af ideerne og lade dem komplementere hinanden. Overvejelser om naiv realisme og egentlig realisme er vedkommende $\mathrm{i}$ forbindelse med evolutionsideens udvikling. Men inden den belyses, vil det være af interesse at se, hvorledes det evolutionære verdensbillede kan give sig til kende.

Gennem en række år har danske arkæologer arbejdet i Den nære Orient med udgravninger i landene langs sydkysten af Den arabiske Golf. Gravhøje og husruiner fra det tredie årtusinde før Kristus på den lille $\varnothing \mathrm{Umm}$ an-Nar ved roden af Oman Halvøen har været genstand for kampagner (Frifelt, 1991), og et større knoglemateriale, der er tolket som køkkenaffald, er blevet bearbejdet (Hoch, 1979; under trykning). Af de omkring 15 arter af krybdyr, fugle og pattedyr, der er påvist ud fra knoglerne, er én uddød (Ardea bennuides, en kæmpehejre), mens de øvrige: havskildpadder, skarv, søkø, oryx, gazeller, ged, okse, dromedarer, hvaler o.a., efter knoglefragmenterne at dømme er eksisterende arter. Når bortses fra tilfældet af uddøen, vidner disse forhistoriske dyrerester således ikke om evolution, men kan beskrives inden for et aktualistisk verdensbillede ganske som almindelige avisnyheder. Af kulturhistorisk betydningsfulde resultater af undersøgelsen er, bl.a., at Umm an-Nar har de tidligste kendte spor af tæmmede dromedarer; og af naturvidenskabelig relevans er knoglernes udsagn om tilstedeværelsen af velkendte dyrearter i den pågældende region for 4.500-5.000 år siden.

Det forhistoriske køkkenaffald viser, at skildpadde og søko hørte til menneskenes vigtigste proteinkilder, ligesom det fremgår af køkkenmøddinger rundt langs de indo-pacifiske kyster. Hvalknogler forekommer også i fundet. Den søko, der er tale om, er dugongen, et stort, marint pattedyr, der lever, foruden ved Arabiens kyster, sydpå langs Østafrika og østpå langs Indien og videre ind i de australasiske vande, fra Yangtzekiangs delta i nord til et stykke ned ad Australiens østog vestkyster i syd. Dugongen er udelukkende planteæder, der græsser på lavt vand langs kyster, som ikke er eksponeret mod det åbne ocean - dugonger kan ikke klare sig $\mathrm{i}$ hård bølgegang, og de trives bedst $\mathrm{i}$ vandtemperaturer på $18^{\circ} \mathrm{C}$ og derover (Brown, 1991). De er følsomme også over for lyd, og de lider stærkt under moderne støj- og anden forurening fra menneskene. En anden slægt af søkøer, manaterne, lever i ferske og salte vande i tilknytning til Atlanterhavets tropiske kyster i det østlige Sydamerika og det vestlige Afrika.

Sirenia, som er den latinske betegnelse for alle søkøer, er beslægtet med elefanterne. Et fællestræk for de to zoologiske ordener er, at to fortænder i overkæben er udviklet som stødtænder. Tilsammen kaldes disse dyr og nogle uddøde former tethytherer (McKenna, 1975), der hentyder til deres opkomst ved Tethyshavet. Dét var det store, fortidige middelhav, der mere eller mindre adskilte det nordlige storkontinent Laurasia fra det sydlige storkontinent Gondwana i Kridt- og begyndelsen af Tertiærtid. I tidlig Tertiær, for omkring 
650 millioner år siden, gav søkøernes stamformer, der var landdyr, sig til at søge føde i vandet langs Tethyshavets kyst. Noget lignende skete med hvalerne, der udviklede sig fra rovdyragtige urhovdyr langs Tethyshavet i tidlig Tertiær. Men mens hvalerne i løbet af Tertiær adapterede sig til oceanerne, forblev søkøerne knyttet til de kystnære, undersøiske enge. Og da den afro-arabiske kontinentplade under sin langsomme bevægelse mod nord stødte ind i Eurasien, blev søkøernes udbredelsesområde delt $\mathrm{i}$ den atlantiske og den indo-pacifiske region (i sidstnævnte blev den kuldetålende Stellers søko ved Beringstrædet udryddet i 1700-tallet, og Middelhavets dugong bukkede under for menneskene endnu tidligere).

Denne palæontologiske udredning hører til det evolutionære verdensbillede. Den indeholder to indbyrdes afhængige evolutionsforestillinger, den biologiske og den geologiske. Det ikke-evolutionære geokoncept, med stabil kontinent-konfiguration, afløstes tilsyneladende $\mathrm{i}$ anden halvdel af vort århundrede af det evolutionære geo-koncept, med mobil kontinent-konfiguration. Det skete med anerkendelsen af teorien om pladetektonik. Spiren hertil kendes imidlertid fra 1596 i Abraham Ortelii Thesaurus geographicus, der omtaler Amerika som revet bort fra Europa og Afrika ved jordskælv og oversvømmelse og følgelig ses liggende udstrakt mod vest (Romm, 1994). Men på trods af, at kontinentforskydningstanken er 400 år gammel eller mere, er det geologiske evolutionskoncept $\mathrm{i}$ sin rene form stadig kun i ringe grad optaget i lægmands livssyn. Viden om uophørlige ændringer af jordskorpens form, af klima, havstrømninger, land/havgrænser etc indgår ikke i samfundsplan- læggernes dispositioner vedrørende langvarig giftdeponering (også i form af teknologiske installationer) og afgrænsning af fredede områder for dyr og planter.

Det biologiske evolutionskoncept er ligeledes kun for alvor begrebet og annammet $\mathrm{i}$ ånd og sjæl hos et fătal, heriblandt nogle medicinere og naturvidenskabfolk, selv om de fleste almentdannede vesterlændinge vedkender sig det evolutionære verdensbillede. Man accepterer gerne eventuelt hoverende over for de af religiøse overbevisninger hæmmede -, at fortidens organismer gennemløb en evolution, der, blandt andet, førte til udviklingen af arten Homo sapiens. Men flertallet undlader at tænke og handle i overensstemmelse med en viden om fremtidig evolution $i$ en biosfære domineret af mennesket på godt og især på ondt.

Biologisk evolution indebærer, at organismer gennem tid ændrer sig til anderledes, beslægtede organismer. Grundelementet er traditionelt arten, der ændrer sig til en ny art. Som eksemplet fra Umm an-Nar viste, synes der dog ikke at være foregået evolution inden for det tidsrum, der kunne kaldes arkæologisk tid, her de senere knap 5000 år. Der er et beslægtet og berømt eksempel fra Ægypten. Hellige ibis-mumier, der blev indsamlet i Saqqara og Theben under Napoleons felttog til Ægypten, blev åbnet og undersøgt i Paris og viste sig at være identiske med den nulevende Threskiornis aethiopicus, den hellige ibis (Cuvier, 1800; Cuvier kaldte fuglen Numenius ibis). De ægyptiske mumier blev sidenhen nævnt som belæg for, at evolution ikke finder sted.

Det var især i den senere del af 1700-og i 1800-tallet, at Europas naturvidenskabelige tænkere beskæftigede sig med ideer 
Fig. 1: "Narbual" og kranium set ovenfra, fra Worms katalog $i 1655$. Wormskrev: Unicornu marinum er en hval, og tolkede det kostbare, snoede horn, som Middelhavskulturerne kaldte enhjorningens, som den arktiske narhvals stodtand. Sandheden og fabeldyret inspirerede Linné til narhvalens videnskabelige navn Monodon monoceros $i 1758$.

Artiklen her er en bearbeiding afforfatterens forelasning $i$ Museumshojskolens museologiske forelesninger på Nationalmuseet 3. marts 1994

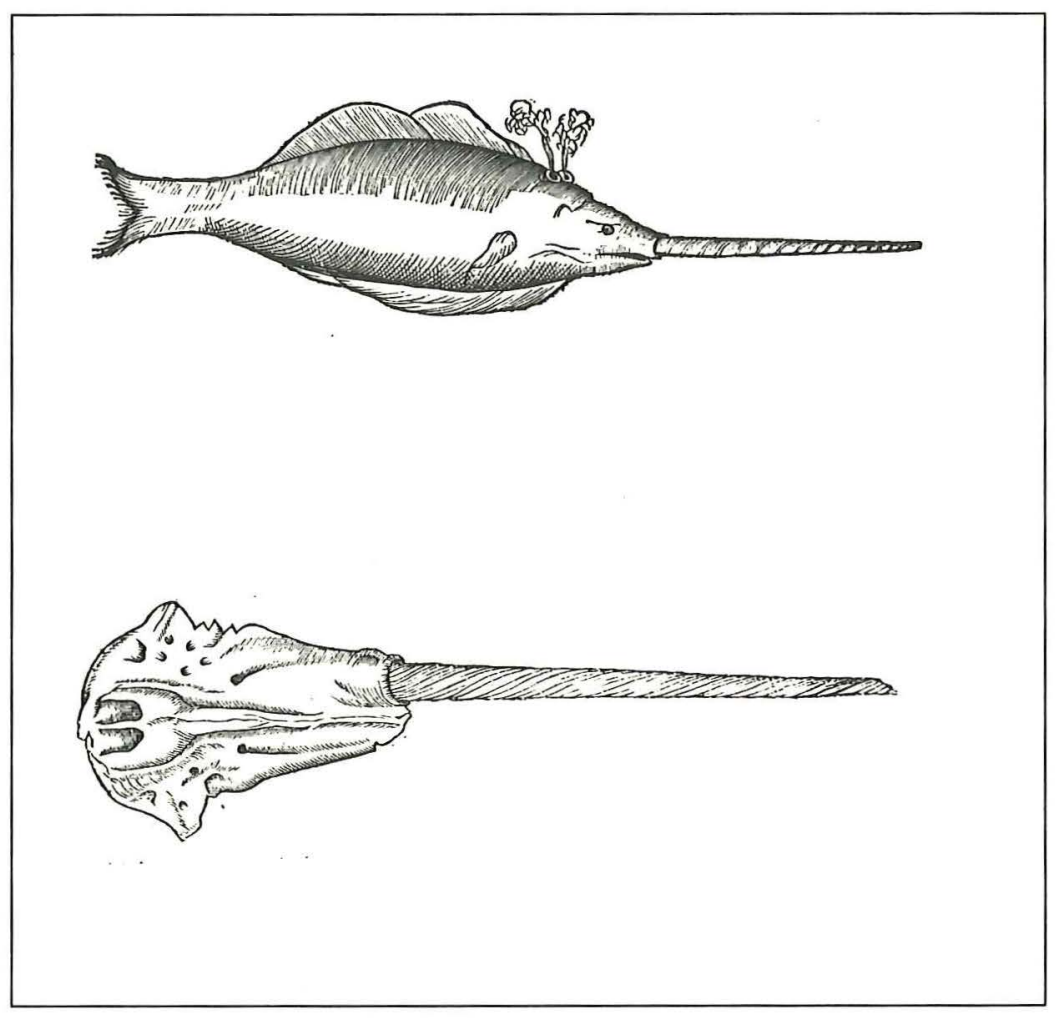

om dyrenes og planternes formmæssige variabilitet. Georges Cuvier, der fra 1795 var knyttet til Det naturhistoriske Museum (Muséum National d'Histoire Naturelle) i Paris og i 1802 blev professor i sammenlignende anatomi sammesteds, anså arterne for at være uforanderlige. Men flere af hans videnskabelige konklusioner indgår i fundamentet for det evolutionære koncept. Cuvier var den, der autoritativt slog fast, at arter kan uddø. Tidligt i sin karriere kortlagde han sammen med geologen Alexandre Brongniart bjergartslagene $\mathrm{i}$ omegnen af Paris. De fossiler af hidtil ukendte dyr, lagene indeholdt ikke mindst de eocæne gipslag, Montmartre gipsen, med fossile fugle, pattedyr og andre større dyr -, var for Cuvier en af evidenserne for, at arter er uddøde igennem geologisk tid. Erkendelsen af, at artsselskabet varierer fra lag til lag, udmøntedes i det stratigrafiske korrelationsprincip, at geologiske lag kan genkendes og adskilles på deres indhold af fossiler. - I England erkendte William Smith princippet på samme tid som Cuvier, men allerede i 1600-tallet var den formative sammenhæng mellem fossiler og sedimentære lag blevet beskrevet af Steno (1669; Hoch, 1987). Stenos tanker blev imidlertid glemt indtil 1832 (se senere). Antoine Laurent de Lavoisier (den berømte franske kemiker, guillotineret i 1794) bestemte geologiske lag efter facies og berørte sammen- 
8 hængen mellem organismer og geologisk miljø, og hans samtidige, Jean-André Deluc udformede tanker om palæontologisk stratigrafi, som Cuvier benyttede (Allègre, 1985; Gohau, 1994).

En anden konklusion af fundamental betydning for udviklingen af evolutionskonceptet kom til udtryk i Cuviers samordning af fossile og recente arter i fælles overordnede taxa. Hermed stadfæstedes et slægtskab mellem uddøde og nulevende arter. Det gjaldt for de uddøde mammutter og de nulevende elefanter, der blev grupperet som Pachydermer, Tykhuder. Det var Cuviers beundrede forgænger ved Collège de France, Daubenton, der havde taget de første forsigtige skridt i denne retning (Pellegrin, 1992). Cuviers arbejdsmetode var den sammenlignende anatomis og funktionelle morfologis, som han raffinerede til det sublime. Ved at se formen af dyret og af hver del af dyret (knogler, tænder, muskler, sanseorganer etc) som afhængig af funktionen (bevægelsesmåde, fødevalg og -indtagelse, formering etc), og dyrets funktion som bestemt af dets form, og ved at se hvert element som en integreret del af den totale, fungerende organisme kunne Cuvier, betinget af sin store erfaring, ræsonnere fra anatomiske detaljer til organisk helhed og fra helhed til detaljer. Ud fra nogle få fossile knogler kunne han genskabe formen af uddøde dyr ved sammenligning med nulevende dyr. Målet for Cuvier var en exakt viden om fortidens verden, som ingen tidligere havde kunnet tilnærme sig gennem andet end myter og fantasi. Hans arbejdsfelt lignede det, der nu kaldes palæøkologi, læren om de fortidige livsformer og miljøer og om vekselvirkningen mellem organismerne og den uorganiske natur. Der var ingen spekulati- oner om familieforhold. Indbyrdes beslægtede arter i cuvier'sk forstand er arter, der formmæssigt og funktionelt ligner hinanden, uden at det er underforstået, at den ene er stamform for den anden, eller at to eller flere af dem har samme stamform.

Cuvier mente, at forskellige geologiske lag indeholder rester af forskellige floraer og faunaer, fordi naturkatastrofer, "revolutioner», med mellemrum gennem Jordens historie har udslettet det levende i varierende geografiske områder. Derefter indvandrede anderledes organismer fra egne, der var uberørt af katastrofen. Jean Baptiste de Lamarck, Cuviers 25 år ældre kollega ved museet, oprindeligt botaniker, der ved revolutionstidens omorganisering af museet blev tildelt et professorat $i$ invertebrat-zoologi, formulerede væsentlige tanker om transformation af organismerne. Dette idékompleks, der indebar en gennem tiden glidende formændring af dyr og planter (der ikke udgjordes af arter), blev totalt forkastet af Cuvier. Idémæssigt kan transformation opfattes som en forløber for evolution, og det er karakteristisk for fransk tænkning at anse darwinismen som bekræftelsen på Lamarcks geniale syn (Pellegrin, 1992). I Nordeuropa ses lamarckismen som darwinismens antitese. Her er der sket et spring fra modsætningen imellem udvikling (Lamarck og Darwin) og ingen-udvikling (Cuvier) til modsætningen imellem to forestillinger om udvikling, og man har stort set "glemt» Cuvier. Det er værd at bemærke, at Darwin var en stor beundrer af Cuvier.

Den forestilling om udvikling, der dominerer i det nordlige Europa - specielt i den angelsaksiske verden - er (videreførelsen af) den, der blev litterært fremstillet 
af Charles Darwin $\mathrm{i}$ On the Origin of Species i 1859 (oversat til dansk af J.P. Jakobsen i 1872). Dette forhold skyldes ikke udelukkende darwinismens hævdede videnskabelige overlegenhed, men har også en årsag i politiske omstændigheder, der førte til anglificeringen af kontinentalEuropas kulturliv, ikke mindst efter de to verdenskrige. Der er en kobling imellem fransk sprog/kultur og lamarckismen. Så længe fransk endnu var benyttet almindeligt i skrift og tale også af nordiske naturforskere, havde lamarckismen tilhængere her (samme tendens kendes fra Rusland). Den ansete danske zoolog Herluf Winge fulgte Lamarcks lære (hans arbejder om pungdyr er stadig velkendte blandt australske forskere). Mens især franskmænd og tyskere næppe nogensinde har forkastet Lamarck fuldstændigt, synes der nu også at være en forsigtig, spirende tendens blandt vestlige engelsktalende naturforskere til at åbne sig for visse lamarckistiske tanker som supplement til den avancerede evolutionsopfattelse.

On the Origin of Species udsiger, at arterne er opstået gennem nedstamning med variation fra beslægtede arter ved en naturlig udvælgelse og overlevelse af de bedst egnede i kampen for tilværelsen. Mens transformation blev begrundet i ydre forhold (klima, føde etc), tilskrives evolution primært indre faktorer, der ytrer sig gennem arv. Darwins tanker adskilte sig kun lidt fra de tanker om evolution, hans jævnaldrende, Alfred Russell Wallace, havde udviklet, og de to teorier blev præsenteret for offentligheden ved samme møde i Linnean Society i London i juli 1858. Men Wallace arbejdede i det Malayiske Arkipelag og Darwin i England, On the Origin of Species var skrevet for den alment dannede borger såvel som for fagfæller, og Darwin fik en stærk og hengiven bannerfører i Thomas Henry Huxley, hvorfor Darwin blev mere kendt - respekteret og forkætret - end den lige så agtværdige Wallace. Deres gensidigt respektfulde optræden i den potentielle konkurrencesituation er en af videnskabshistoriens fineste hændelser. Begges ræsonnementer var baseret på årelange observationer af organismerne og deres miljø i flere verdensdele, og $\mathrm{i}$ begge tilfælde var den praktiske baggrund indsamling af biologiske objekter til liebhavere og museer.

Forestillingen om et fylogenetisk udviklingsforløb fra mere primitive til mere avancerede former vakte voldsom debat, og heftig aversion blandt bibeltro mennesker. Evolutionslæren blev opfattet som en forkastelse af skabelsesberetningen i bogstavelig forstand - hvilket den vitterligt er. Ikke mindre frastødende, men næppe så klart erkendt af moderne danskere, var det element af den ny videnskabelige teori, der exponerede mennesket nøgent, som et dyr udviklet fra andre dyr. Hermed krænkedes et kulturelt tabu, der udadtil ytrede sig i, at det europæiske borgerskab, dets fruer og frøkener i særdeleshed, offentligt knap havde kødelig krop og ben.

Naturlig udvælgelse og konkurrence er gennemgående temaer $\mathrm{i}$ darwinismen. Negativt anskuet er "survival of the fittest" en stadfæstelse af jungleloven, ikke mindst når tesen applikeres på sociologien. Herbert Spencer fulgte de samme idébaner som Darwin i sine ræsonnementer over menneskenes samfund og kulturer, og ekstremerne af disse tanker gav næring til racismen. Stadig er det imidlertid et spørgsmål, om evolution virkelig foregår som tentativt foreslået af Darwin. Sandt er 
10 det, at i en geologisk lagfølge, der afspejler pålejring af ler, sand eller andre bjergarter gennem tiden, repræsenterer fossile rester af organismer $\mathrm{i}$ de nedre og gamle lag uddøde arter, og opadtil gennem lagfølgen findes der arter, der jo nærmere de er nutiden desto mere ligner de nulevende organismer. Vi forklarer det ved, at der er sket en evolution. Men er vi rigtigt i stand til at følge slægtsliniers ændring nedefra opefter i lagfølgen?

Et af problemerne i naturen er, at roligt og kontinuert aflejrede geologiske lagfølger, der spænder over meget store tidsrum, og som indeholder velbevarede fossiler fra samme hovedtype af miljø, sjældent findes nemt tilgængelige og studérbare. Sammenpresninger, opskydninger, foldninger og andre følger af jordiske kraftudfoldelser har $\mathrm{i}$ vid udstrækning modificeret de oprindelige lag, og hvor lagsekvenser er eksponerede ved jordoverfladen, er de ofte mere eller mindre skjult under forvitringsdækker og vegetation. I løbet af en langvarig aflejringsfølge kan der foregå skift af miljø, f.eks. fra hav til land ved en hævning, hvorved der selvsagt kommer ny organismer ind i billedet, uden at det behøver at betyde, at de foregående er uddøde eller forandrede - de kunne have flyttet sig med deres foretrukne naturforhold, i dette tilfælde havet. Et sted, hvor der findes lagfølger afsat kontinuert gennem lange tidsrum, med organisk indhold og i stort set samme miljø, er i bunden af dybhavet. Borekerner herfra har afsløret overraskende udviklingsfølger.

Mikrofossiler i dybsøborekerner viser, at en art kan uddø, uden at der tilsyneladende sker noget med de øvrige arter i miljøet, dvs uden at der er en synlig miljøændring, og uden at der er en konkurrent
(Emiliani, 1993). Før eller siden kan en ny form dukke op i den forsvundne arts $ø$ kologiske niche, eventuelt muteret fra en anden art og ikke nødvendigvis "mere egnet» end den uddøde form. Denne slags uddøen forklares (af Emiliani) som forårsaget af havvirus. En sådan type af forsvinden af arter forekommer ret almindeligt og giver anledning til at tro, at arter kan være stort set stabile over lange tidsrum, derpå uddø, hvorefter en ligeledes stort set stabil arts afvigere tilpasser sig og bliver til en ny stabil art i den ledige niche.

Forløbet ligner det, der i evolutionsdebatten kaldes springvis (punktualistisk) evolution. Denne foregår principielt inden for samme slægtslinie ved kortvarig, kraftig evolution efterfulgt af langvarig evolutionær stilstand efterfulgt af kortvarig, kraftig evolution etc. Herimod står den glidende (gradualistiske) evolution, der er den jævnt fremadskridende ændring af arter, som menes at kunne finde sted, for eksempel under roligt klimaskifte. Der synes at være slægtslinier op igennem geologiske lagserier, der viser en gradvis ændring af organismernes form. Finder man fossiler fra to tidsmæssige yderpunkter af en sådan udviklingsfølge uden at have mellemformerne, kan de blive beskrevet som to arter, den ene som stamform for den anden. - At der, som i tilfældet med Umm an-Nar knoglerne og de ægyptiske ibis-skeletter, ikke kan spores formmæssig ændring inden for 5-6000 år, kunne tages til indtægt for ideen om punktualistisk evolution. Men tidsrummet er meget kort geologisk set, hvilket maner til forsigtighed.

Det virker, som om nutidens samlede opfattelse af evolution harmonerer med Koliadins ønske om komplementerende 
frem for konkurrerende ideer. Vi har overstået tilstanden «For eller imod evolution!», der grasserede i de vestlige samfund og satte videnskab og religion i skarp opposition. Vi er nået til en modnere fornemmelse af foranderlighed og usikkerhed. Grænsen mellem liv og livløst, mellem organisk og uorganisk, der var blevet trukket hårdt op gennem de foregående århundreders rationelle analyser af Middelalderens spekulative forestillinger, blødes atter op: troen på, at mus bliver til af støv og smuds i mørke kroge, blev forkastet, men vi accepterer nu, at diamanter kan være dannet af døde bakterier. Forklaringen hører til i det evolutionære verdensbillede: lette kulstof-isotoper fra arkæiske bakterier, der levede omkring hydrotermale uddunstninger på oceanbunden, blev ved oceanpladens subduktion (af lat. sub-, under; duco, føre, lede; neddykning $\mathrm{i}$ Jordens kappe under en anden oceanplade) udsat for extreme fysisk/kemiske forhold og blev muligvis via stadiet grafit omdannet til diamant (Nisbet et al., 1994). En stiv tro på, at fossiler altid repræsenterer stamformer for senere arter, er også overkommet. For mammuttens vedkommende var Cuviers opfattelse mere sober end dén evolutionists, der vil se mammutten som stamform for de nulevende elefanter. Sammenligning med andre dyr viser, at mammutten er ekstremt specialiseret og ikke kan være stamform for de nulevende, primitivere elefanter. Derimod kan mammut og nutidens elefanter have samme stamform og være fylogenetisk beslægtede med hinanden. I erkendelse af evolutionsprocessens uhyre kompleksitet er vi blevet mere tilbøjelige til at føle os frem mellem variationerne af naturlig udvikling, så vidt vi kan ane dem, snarere end stejlt at hævde én forklaringstype. - «Vi» er dog ingenlunde menneskeheden som sådan, men kun en vis, hvad angår evolution, toneangivende mængde af mennesker i den vestlige kulturkreds og epigoner andre steder.

\section{ERKENDELSEN BETINGET AF SAMLINGERNE}

Blikket kastes nu tilbage $\mathrm{i}$ historien for at uddybe museernes rolle i denne teoriudformning. De store opdagelses- og erobringsrejser, fra 1400-tallet og fremefter, og de exotiske genstande, væsner og beskrivelser fra fjerne egne, der samledes i Europa, blev bearbejdet af sind, der i Renaissancens ånd dyrkede ratio, fornuften. Hen mod 1700-tallets slutning kunne Europas ledende forskere med rette føle, at de nu kendte Jordens kontinenter tilstrækkeligt til, at der ikke længere ville komme overraskelser i form af helt ukendte, store dyr. Cuvier kunne tillade sig at hævde, at mammutten er uddød, for det var utænkeligt, at der kunne leve så bemærkelsesværdigt et dyr noget sted, uden at europæerne vidste om det. Tørrede, skeletterede, udstoppede, spritkonserverede eller på anden måde bevarede rester af organismer fyldte hylde efter hylde på Europas museer, heriblandt Det naturhistoriske Museum i Paris, der skyldte Revolutionen sin opblomstring og moderne organisation. Cuvier fortsatte med flid den før hans tid påbegyndte opbygning af en samling af alle eksisterende arter og udvidede interesseområdet med fossilerne. En stor del af stykkerne modtog han fra korresponderende kolleger og samlere i hele Europa. Han skabte et imponerende net af kontakter til personer, 
12 der dels sendte materiale til ham (Taquet, under trykning), dels nød godt af den prestige det gav at kende Cuvier (Outram, 1979). Selv sad han i det kulturelle centrum og havde magt til at mene - i Revolutionens ånd -, at de riges dilettantisme og forskernes fattigdom gør, at statens støtte er nødvendig, for at de sidstnævnte kan opbygge de samlinger, der er uundværlige for videnskabens fremskridt (Pellegrin, 1992).

Som omtalt, var det geo-evolutionære billede allerede klart antydet i slutningen af 1500-tallet. At ideen ikke fik nogen mærkbar effekt på den følgende tids videnskab kunne skyldes, at Ortelius præsenterede den så diskret (jf. Romm, 1994), at ingen indflydelsesrige tænkere opdagede den. Anderledes med det bio-evolutionære billede, der tilsyneladende ikke for alvor kan spores på denne side af Renaissancen førend op i 1700-tallet. Niels Stensen, Steno, der er en markant eksponent for 1600-tallets anatomer, og som ræsonnerede over tilblivelsen af fossiler, krystaller og den yderste jordskorpes former længe før termen geologi eksisterede, nærmede sig ikke begrebet evolution. Hans berømte Prodromus blev udgivet i Firenze 1669 under kirkelig censur, som var almindelig dengang (som noget bemærkelsesværdigt havde Nederlandene religionsfrihed, da Steno var på studieophold i Amsterdam og Leyden). Det var dog nok mindre den ydre end den indre censur, $i$ form af en ren, kristelig tro, der afholdt Stenos tanker fra at bevæge sig $\mathrm{i}$ den pågældende retning. Der manglede også så væsentlige forudsætninger som viden om de levende organismers mangfoldighed og kendskab til fossiler ud over det aller mest elementære.
Af Chaos-manuskriptet, Niels Stensens dagbog gennem tre måneder i 1659 under studietiden i København, fremgår det med rørende klarhed, hvilke umådelige vanskeligheder et ungt, opvakt og belæst menneske havde med at skelne virkelighed fra metafysik og overtro. Efterslæbet fra Middelalderen var endnu særdeles mærkbart i Frederik IIIs København. Dagbogen består af alskens noter, citater og reflektioner, som han nedfælder, når han sidder stille, sikkert oftest i forbindelse med sine mere eller mindre ihærdige studier på Universitetsbiblioteket øverst i Trinitatis Kirke:

Onsdag den 11 maj 1659 ... Man siger, at enebærbuskens skygge ikke er ret sund. Måske tilfører en formørkelse af solen og andre (himmellegemer) luften skadelige egenskaber. [---] Onsdag den 30. marts 1659 Uddrag af Kircher: ... En raslesten bundet til en barselkvindes lår fremskynder fødselen, idet den virker kraftigt på livmoderen, som derved sættes $\mathrm{i}$ bevægelse. En raslesten er frugtsommelig med en anden sten.

En anden note fra den samme dag viser Niels Stensen som den spirende forsker:

Man synder mod Guds majestæt ved ikke at ville betragte naturens egne værker, men lade sig nøje med at læse andres værker; man danner og skaber sig derved forskellige opdigtede forestillinger og går ikke blot glip af nydelsen ved at betragte Guds undere, men spilder også den tid, der skulle bruges til nødvendige ting og til sin næstes gavn, idet man fastslår mange ting, som er Gud uværdige. Sådanne er disse skolastikere, sådanne er de fleste filosoffer og de, der bruger hele livet på studiet af logik. Tiden skal ikke bruges til forklaring og forsvar for disse anskuelser, ja næppe nok på deres undersøgelse, og man skal ikke dristigt og hovedkuls henføre 
noget til kunsten på grundlag af en enkelt tings betragtning. Min tid vil jeg herefter ikke anvende til grublerier, men alene til undersøgelse, erfaring og nedskrift om naturgenstande og de gamles beretninger om iagtttagelsen af sådanne ting samt efterprøvelse af disse beretninger, hvis det er muligt.

Som barn kom Niels Stensen på Museum Wormianum, Worms Museum. Professor Ole Worm døde i 1654, da Steno var 16 år gammel, og derefter overgik genstandene til Frederik IIIs Kunstkammer og blev utilgængelige for lægmand. Worm havde brugt sit museum til undervisning af de studerende ved Københavns Universitet. Han var en foregangsmand som lærer i naturfag, der ønskede at give ungdommen kendskab til objekterne og virkeligheden, og det er givet, at han og Museum Wormianum med den ny tidsånd har præget Steno (Christiansen \& Moe, 1986). Det var i Worms Museum, Niels Stensen først så tungesten, glossopetrae. Sådanne objekter var velkendte i europæiske raritetskabinetter (mange stammede fra Tertiærtidens aflejringer på øen Malta), og der blev givet flere forklaringer på deres tilblivelse (jf. Scherz, 1969). Steno var en af de første eller måske den første efter Renaissancen, der dels påviste, at de oprindeligt var hajtænder, dels klart definerede begrebet fossil: han skrev i Prodromus, "at de legemer, som udgraves af jorden, og som i alle henseender ligner dele af planter og dyr, er frembragte på samme måde som selve planternes og dyrenes dele». Det skete under hans ophold i Toscana, hvor han var inviteret til at forske som anatom i Firenze, på den tid et af Europas stærke kulturcentre, af Storfyrst Ferdinand II af Mediciernes slægt.

Den unge Steno var blevet sendt på stu- dierejse i Europa i efteråret 1659. Særligt i Leyden og Paris udmærkede han sig som anatom og fysiolog og udviklede sig intellektuelt i niveau med de bedste i sin tid. Stenos vidtspændende rejseaktiviteter og akademiske færden i Europa er velpublicerede (f. eks. Scherz, 1969). Her skal alene refereres til hans voksende opmærksomhed over for naturen og dens geologiske og palæontologiske fænomener i de italienske lande, som han kom til efter Paris og Montpellier, i 1666. I Firenze udarbejdede Steno en katalog, Indice, over Mediciernes samlinger og hans egen samling af mineraler og fossiler. Det er bemærkelsesværdigt, at Stenos samling, til forskel fra de fleste af hans samtids, var del af hans forskningsprogram (Spärck, i Scherz, 1969:24), der resulterede i publikationen af Prodromus. Dette lille, nu berømte værk - en tid glemt, men genfremdraget af Elie de Beaumont i 1832 (Hoch, 1985) - indeholder kimene til palæontologien (om fossilerne), stratigrafien ("Stenos superpositionsprincip») og krystallografien ("loven om kantvinklens konstans»).

Renaissancen var genfødelsen af de klassiske idealer. Med trangen til viden opstod moden at samle rariteter - konger gjorde det, hertuger, professorer og borgere med udsyn, hver i sin målestok - for at betragte genstandene, beskæftige sig med dem, undre sig over dem, vise dem frem, passe på dem, og, vigtigst, for at søge deres forklaring. Således blev museerne til. Her samledes belæggene for naturens ufattelige variation og rigdom. Herfra voksede tankerne om Jordens, dyrenes og planternes tilblivelse og om virkelighedens processer.

En gammel bog i Geologisk Museums arkiv, Neueste Beschreibung Von Alt und 
ELLA $\mathrm{HOCH}$

14 Neu Groen-Land af Simon von Vries (1679), har i brevform overleveret et livfuldt og gribende billede af begejstringen under en videnskabelig erkendelses tilblivelse. Det sker i niende kapitel: Worinne gehandelt wird von den kostbaren Zähnen/ die man Einhörner nennet. Forfatteren omtaler såvel de nyere naturkundiges som Biblens, Aristoteles' og Plinii opfattelser af enhjørningen som et firfodet landdyr med et langt, snoet horn i panden - efter Plinius: med hjortehoved, hestekrop, så stærke hofter som en elefant og en usammenlignelig hurtighed og styrke. Under et fælles besøg i Christianstad, fortæller Simon von Vries, var han gerådet $i$ en vidtløftig ordstrid med Ole Worm, der «er den første, der har berettet for mig, at den [enhjørningen] er en fisk». Han citerer derpå et brev fra «Herr Wurm» (Fig.1 og 2):

Der er nu gået nogle år, siden jeg befandt mig hos $\mathrm{Hr}$ von Frisen, Rigskansler i Danmark, og forgænger for $\mathrm{Hr}$ Thomassorn, der nu beklæder denne post, og beklagede mig til denne fornemme mand (der gennem sin livstid var sit fædreland en god støtte) over manglen på flid hos vore sø- og handelsfolk, der rejser på Grønland og dog ikke rigtigt udforsker og søger oplysninger om, hvilke dyr det er, hvis horn de fører med sig tilbage; og heller ikke tager et stykke kød eller hud med, så at man kunne få et bedre kendskab til dem.

Herpå gav han mig til svar: De er måske mere omhyggelige end De tror. Lod straks bringe en stor, ganske udtørret hovedskal ind, hvori stak en stump af den samme slags horn, omkring fire fod lang. Jeg blev ikke så lidt oplivet over at se en så sælsom og kostelig ting i mine hænder. Mine øjne kunne ikke se sig mætte på den, og det var mig til at begynde med ubegribeligt, hvad dette dog kunne være. Bad derfor, om $\mathrm{Hr}$ Kansleren ville tillade mig at tage dem med mig hjem, så at jeg kunne få tid til at se nøjere på den, hvad han gerne gav mig.

Her fandt jeg nu, at denne hovedskal i sandhed lignede hovedet af en hvalfisk; for den havde i den øverste del to huller, der gik igennem fra hovedets overside til munden. Uden tvivl er disse huller åbningerne af de to rør, hvorigennem denne fisk sprøjter det vand ud, der er fosset ind. Jeg bemærkede også, at dét, som man kalder dens horn, sad fast i den venstre del af overkæben. Derfor tilkaldte jeg de allermest nysgerrige af mine venner, sammen med mine bedste tilhørere og elever, så at de kunne være med til at se denne raritet på mit værelse. Tillige lod jeg en maler komme, der under alle disse tilskueres tilstedeværelse afbildede formen af dette kranium med ét horn, i den nøjagtige form og størrelse, således at de alle kunne bevidne, at afbildningen er vellignende efter selve den sande original eller oprindelige genstand. [Se videre Fig. 2]

\section{REJSE UDEN RETOUR}

Således avancerede vi fra Middelalderens spekulative verdensbillede, skridt for skridt - så, lyttede, følte os frem til en opfattelse af virkeligheden begrundet i objekternes form og struktur, deres indbyrdes relationer og materiens processer. Belæggene for denne virkelighedsopfattelse er museernes indhold. // Irans vismænd græd, da Amerikas rummænd betrådte Månen - poesien blev voldtaget. Vi græder selv over tabet af ydmygheden for det ufattelige. Museerne er det evolutionære verdensbilledes relikvieskrin. Konsekvenser af vor ny tro er lige så forfærdende som den gamle tros skræmmebilleder. // På Hanstholm Museum fortælles om den danske urt benbræk (Narthesium ossifragum). Den fik sit navn i gamle dage, fordi kvæget, der gik ude på jorder, hvor den voksede, tit brækkede benene. Man gav planten skylden for ulykkerne! Men ben- 
MUSEERNE OG DET EVOLUTIONÆRE VERDENSBILLEDE

Fig. 2: Efter Vries

(1679), pp. 27-28.

Fotografisk kopix 0,67.

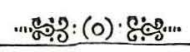


16 bræk har den særlige egenskab at kunne trives på kalkfattig jord - den gyldne blomst var uskyldig. De uvidende mennesker skulle have givet kvæget kalk for at gøre dets knogler stærke. Videnskaben, der ændrede vor forståelse af verden, løftede overtroens tunge åg af vore skuldre og bragte hekseforfølgelserne til ophør.

Museerne er rødder på Kundskabens Træ. Og nu har vi spist af det. Adapteret til det evolutionære verdensbilledes virkelighed, som er udvikling, er vi i stedse opposition til det stationære verdensbilledes dyrkere, som er de religiøse fundamentalister. Med vor accelererende aktion i naturvidenskabelig formån, langt ud over hvad vi selv kan tøjle, provokerer vi den politiske reaktion, der nok så meget er udtryk for frygt som for rovgriskhed. Men skal individer stenes for at holde samfundet på traditionens snævre sti? Men skal Månen besudles for at vi kan få mere at vide? - På Geologisk Museum ligger et stykke af Månen. Vi kender, nu, dets petrokemiske sammensætning.

\section{RÉSUMÉ}

Les musées, berceaux de la conception évolutionniste du monde

Les idées relatives aux sciences naturelles, telles qu'elles se sont développées en Europe depuis la Renaissance, sont fondées sur l'observation des objets et le principe du rationalisme.

La pénétration objective de l'analyse scientifique donne satisfaction aux cervaux avides. Mais la dénudation indiscrète du fond des choses et des phénomènes cause de la douleur aux sentiments humanistes, soit lyriques, romantiques, religieux,

Science! true daughter of Old Time thou art! Who alterest all things with thy peering eyes.
Why preyest thou thus upon the poet's heart Vulture, whose wings are dull realities? How should he love thee? or how deem thee wise, Who wouldst not leave him in his wandering To seek for treasure in the jewelled skies, Albeit he soared with an undaunted wing? Hast thou not dragged Diana from her car? And driven the Hamadryad from the wood To seek a shelter in some happier star?

Hast thou not torn the Naiad from her flood, The elfin from the green grass, and from me The summer dream beneath the tamarind tree?

Le Sonnet - to Science d'Edgar Allan Poe (1845) nous touche profondément, tout comme beaucoup d'entre nous ont le coeur serré de crainte face au futur de la biosphère qui est menacée par maintes activités scientifiques, dont les plus récentes sont celles des techniciens de la génétique moléculaire.

Dans le but de présenter une vision scientifique évolutionniste nous nous tournons vers le ProcheOrient. Les travaux archéologiques du dégagement des ruines des maisons situées à l'île d'Umm anNar sur la côte ouest de la Péninsule d'Oman ont procuré une grande collection de fragments d'os. Ces restes des ordures ménagères du troisième millénaire av. J.C. indiquent la présence, parmi les vertébrés hormis les poissons, d'environ quinze espèces de tortues, oiseaux et mammiferres, dont une seule Ardea bennuides, un héron gigantesque - est éteinte (Hoch,1979, sous presse). Pour les autres, les ossements ne montrent que des caractères morphologiques qui correspondent aux traits squelettiques normaux des espèces vivantes. Pour les tortues marines, les cormorans, les dugongs, les oryx, les dromadaires, les baleines etc, il n'a pas été constaté des signes d'évolution, ce qui permet une vision scientifique actualiste et fixiste. Le dernier terme fait référence à la position géographique de l'Arabie (comprise Umm an-Nar) par rapport aux continents qui l'entourent. Mais un coup d'oeil sur les restes fossiles des ancêtres du dugong, les "pro-siréniens» ter- 
restres et les "paléo-siréniens" de l'Océan Téthys, et sur leur distribution paléobiogéographique, nous montre une évolution des siréniens pendant 50 millions d'années, et une déplacement de la plaque afro-arabique vers le nord, qui a coupé la Téthys et isolé les lamantins de la région atlantique des dugongs des mers indo-pacifiques. Cette vision évolutionniste est issue de la Paléontologie et la Géologie.

Le concept d'évolution géologique est devenu populaire avec la théorie de la tectonique des plaques dans la deuxième moitié de notre siècle. Mais l'indication la plus ancienne connue d'une interprétation mobiliste de la position des continents fut publiée par le cartographe Abraham Ortelius en 1596 (Romm, 1994). Pourtant l'ancienneté de cette idée qui date d'environ 400 ans n'a pas suffi pour faire vraiment accepter à tout le monde, que la croûte terrestre n'est pas stable, mais qu'elle est susceptible de mouvements aussi bien horizontaux que verticaux, de l'érosion et de l'édification des roches, du transport des sédiments de toutes sortes, des transgressions et des régressions des mers, des changements du climat dus aux déplacements relatifs des terres et aux variations de la radiation solaire, etc. Les planificateurs de nos sociétés, qui procédent en notre nom, installent des dépôts de déchets hypertoxiques et délimitent des réserves floralesfaunistiques sans se soucier du fait acquis que la Terre évolue.

De même, tandis que nombre de médecins et de naturalistes sont des évolutionnistes par conviction, la grande majorité des soi-disant disciples du concept d'évolution biologique ne le sont pas totalement. Ils sont persuadés - souvent avec un air de supériorité vis-à-vis des croyants anti-évolutionnistes - qu'il y a eu une évolution des organismes depuis l'origine de la vie jusqu'à ce jour; mais ils ignorent - délibérément? - la continuation inévitable de l'évolution, donc la gravité du comportement humain quant à notre pollution et notre manipulation de la biosphère.
La fin du XVIIIe et le XIXe siècle en Europe ont explications transformistes/évolutionnistes quant au problème de la variation des organismes soit contemporains, soit au cours du temps. Georges Cuvier, l'illustre naturaliste qui donna à l'Anatomie comparée et à la Paléontologie ses lettres de noblesse (Taquet, sous presse) - attaché depuis 1795 au Muséum National d'Histoire Naturelle à Paris où il obtint en 1802 la chaire d'Anatomie comparée - soutenait l'immutabilité des espèces. Mais ses conclusions scientifiques, telles la thèse de l'extinction des espèces et le regroupement taxonomique des espèces récentes avec des espèces fossiles, ont contribué au fondement du concept d'évolution. Les méthodes de travail de Cuvier étaient raffinées à l'extrême. Sous son autorité des animaux furent disséqués, étudiés et préparés pour l'enseignement et la conservation, conformément au plan conçu par son prédécesseur au Collège de France, Daubenton, de collectionner tous les êtres naturels. D'après Cuvier, et en plein accord avec la notion révolutionnaire et républicaine de son époque, le dilettantisme des riches et la pauvreté des savants font que seul l'appui de l'État à ces derniers peut leur permettre de constituer les collections indispensables au progrès des sciences (Pellegrin, 1992).

Au début de sa carrière muséale Cuvier, en collaboration avec le géologue Alexandre Brongniart, a étudié les couches sédimentaires du Bassin de Paris, $d$ 'où fut tiré le principe de corrélation entre strates géologiques sur la base de fossiles (sur la stratigraphie paléontologique et Nicolas Sténon, Antoine Laurent de Lavoisier, Jean-André Deluc et William Smith, vide Stenonis, 1669, Allègre, 1985 et Gohau, 1994), et il établit de grandes collections de fossiles du Muséum. Du gypse de Montmartre venaient les restes d'une faune et d'une flore tout à fait différente de celles de l'Europe actuelle. Cuvier a thésaurisé des données scientifiques, à savoir des informations, des moulages et des pièces originales 
ElLA HOCH

18 de toute l'Europe, pour construire une grande oeuvre sur les animaux disparus (Recherches sur les ossemens fossiles) (Taquet, sous presse). Parmi les fossiles, les oiseaux et mammiferes surtout furent étudiés par Cuvier qui appliquait ses méthodes rigoureuses de l'Anatomie comparée pour faire des interprétations et des reconstructions exactes des formes des organismes et des «anciens mondes». Pour Cuvier, les changements des faunes et des flores d'une couche à l'autre dans la série stratigraphique $s^{\prime}$ expliquent par des catastrophes naturelles et non pas par la transformation des organismes ou l'évolution des espèces. C'est en $s$ appuyant sur les grandes collections muséales, reflet des conditions de la nature, que Cuvier a pu établir la thèse de l'extinction des organismes.

Le collègue de Georges Cuvier, Jean-Baptiste de Lamarck, d'abord botaniste puis avec la réorganisation révolutionnaire du Muséum à Paris, professeur de Zoologie des Invertébrés, fut le grand transformiste; et les anglais Charles Darwin et Alfred Russell Wallace vers 1859 (année de la publication de On the Origin of Species) furent les grands évolutionnistes qui simultanément, l'un de Londres, l'autre de la Malaisie, présentèrent au monde scientifique et laïque des idées évolutionnistes presque identiques. - Le concept de transformation biologique correspond à une mutation progressive des plantes et des animaux due à des agents extérieurs, tandis que l'évolution correspond à une mutation des espèces par des agents internes. On peut noter une particularité culturelle, à savoir que pour I'Europe francophone Lamarck est le "génial visionnaire, à qui le darwinisme aurait finalement donné raison" (Pellegrin, 1992:6), tandis que dans l'Europe du Nord le lamarckisme est considéré comme l'antithèse du darwinisme. - Les idées et les oeuvres de tous ces grands esprits se sont inspirées des objets naturels collectionnés pour des cabinets d'Histoire naturelle et des musées.

Après la Renaissance, l'un des premiers à donner une interprétation correcte des fossiles est Nicolas
Sténon. Son journal personnel, qui s'ouvre par In nomine Iesu CHAOS et qui date du 8 mars au 3 juillet 1659 - période du siège de la capitale du Danemark par les Suédois, quand Sténon était jeune étudiant à l'Université - le montre pénétré d'incertitude intellectuelle, oscillant entre des idées scolastiques, rationnelles et superstitieuses, tout en étant pieux protestant. Il quitta Copenhague pendant l'hiver de 1659 pour un grand voyage d'études en Europe. C'est surtout à Leyde et à Paris que ses talents pour l'anatomie et les dissections atteignirent toute leur ampleur. Son niveau intellectuel égalait alors les meilleurs de son époque. Invité à faire des études d'anatomie à Florence, centre culturel important, par le Grand Duc de Toscane Ferdinand II de Médicis, Sténon profita ainsi d'occasions multiples pour voyager, étudier et collectionner des objets paléontologiques et géologiques dans les paysages italiens. Il prépara un Index des choses naturelles, un catalogue des collections d'objets scientifiques appartenant aux Médicis et de ses propres fossiles et minéraux (Scherz, 1969). Sa collection, à la différence de la majorité des collections de curiosités contemporaines, faisait partie d'une recherche planifiée, d'où résulta son Prodromus (1669). Ce petit livre est fameux pour ses thèses sur les fossiles, la stratigraphie et la cristallographie (Hoch, 1985). Sténon n'aborda jamais le sujet de l'évolution. Il est vrai que tout ouvrage publié était sousmis à la censure de l'Eglise, mais sa foi crétienne très pure "censurait» ses propres pensées peut-être plus que ne le faisait l'Eglise. L'obstacle pratique majeur demeurait pourtant la connaissance imparfaite des organismes et de la Terre.

Sténon arriva à la notion de fossile par l'étude des spécimens tels que les glossopètres qu'il compara avec des dents de requins. Des glossopètres lui étaient connus depuis son enfance à Copenhague, où il les avait vus au Museum Wormianum, le Muséum de Worm. Le Professeur Ole Worm professait des idées pédagogiques très modernes en utilisant des objets de son musée pour l'instruction de 
ses étudiants à l'Université. Après sa mort en 1654 , quand Sténon avait 16 ans, le muséum fut inclus dans le patrimoine du roi Frederik III, et les spécimens devinrent inaccessibles pour les étudiants. Pour souligner l'importance non seulement de l'étude des objets pour l'avancement de la science fondée sur la raison, mais aussi pour montrer l'enthousiasme et le génie du chercheur souhaitant que soient répendues des idées saines, une lettre de Worm pour Simon von Vries sur la vraie nature de la licorne est reproduite du livre Neueste Beschreibung Von Alt und Neu Groen-Land (1679) (Fig.2; et Fig. 1).

Tels furent les progrès depuis la conception spéculative du monde; pas à pas, nous avons observé, écouté, tâté le terrain afin de mieux comprendre la vérité telle qu'elle est sur la base des formes et des structures des objets, des relations mutuelles des choses, et des réactions naturelles. Les preuves de cette perception de la réalité sont le contenu des musées. // Les sages de l'Iran pleurèrent quand les astronautes de 1'Amérique mirent le pied sur la Lune - la poésie fut violée. Nous pleurons nousmêmes la perte de l'humilité pour l'incompréhensible. Les musées sont des reliquaires de la conception évolutionniste du monde. Les conséquences de notre nouvelle foi sont aussi effrayantes que les fantômes de la foi ancienne. // Le Muséum de Hanstholm raconte l'histoire de la petite fleur jaune du nom danois de benbrek, brise-os (Narthecium ossifragum). Autrefois, le bétail élevé sur des patûrages riches en brise-os se cassait souvent les jambes. La maudite plante, disait-on, était coupable! Mais des recherches scientifiques ont démontré que la plante pousse au sol pauvre en chaux, qui cause une décalcification des os du bétail. La Science, qui a changé notre compréhension du monde, a soulevé le joug lourd de la superstition de nos épaules et écarté les chasses aux sorcières.

Les musées font partie des racines de l'Arbre de la Science. Nous avons goûté ses fruits il y a longtemps. Déjà adaptés à la réalité de la conception évolutionniste du monde, à l'évolution, nous sommes en contraste avec les partisans de la conception statique du monde, qui est celle des religieux fondamentalistes. Par l'accélération de la Science nous provoquons des réactions politiques graves, plus en raison de la méfiance que de la rapacité. - Au Muséum de Géologie de Copenhague se trouve un fragment de la Lune. Nous en connaissons, déjà, la composition pétrochimique.

\section{TAK - REMERCIEMENTS}

Stefan Bernstein og Kaj Strand Petersen takkes for deres engagement og værdifulde kommentarer under tekstens tilblivelse. - Je remercie Philippe Taquet d'avoir avec beaucoup de tact refaçonné les expressions maladroites inévitables du résumé.

\section{BIBLIOGRAFI}

Allègre, C.-J. 1985. De la Pierre à l'Étoile, Fayard Brown, J.N.B. 1991. Dugongs - a summary of their status in the UAE. Tribulus 1(1), 20-21

Christiansen, P.A. \& Moe, H. 1986. Niels Stensens barndom og studentertid i København. En biografisk indledning. I Niels Stensen. En dansk student $i 1659$ og noterne $i$ hans Chaos-manuskript ved H.D. Schepelern. Nicolaus Steno Gildet, København, XI-XV

Cuvier, G. 1800. Sur l'Ibis des anciens Égyptiens. Genoptrykt i 1. udgaven af Recherches sur les ossemens fossiles, 1812, og i 1992-udgaven af samme, præsenteret af Pierre Pellegrin, se dér

Darwin, C. 1859. On the Origin of Species by means of Natural Selection, or the Preservation of favoured Races in the Struggle for Life, London.

[Reprinted, ed. J.W. Burrow, London, 1968]

Emiliani, C. 1993. Viral extinctions in deep-sea species. Nature 366, 217-218

Frifelt, K. 1991. The Island of Umm an-Nar, Vol.I, Third Millennium Graves. The Carlsberg Foundation's Gulf Project. Jutland Archaeological 
Society Publications XXVI:1

Gohau, G. 1994. Lavoisier, un géologue méconnu. La Recherche 25, 436-437

Hoch, E. 1979. Reflections on Prehistoric Life at Umm an-Nar (Trucial Oman) Based on Faunal Remains from the Third Millennium B.C. In M. Taddei (ed.) South Asian Archaeology 1977, Naples, 589-638

Hoch, E. 1985. Sténon et la Géologie. Géochronique 15, 21-22

Hoch, E. 1987. Towards biostratigraphical reasoning. Abstract. Terra cognita 7(2-3), 216

Hoch, E. (under trykning). Animal Bones from the Umm an-Nar Settlement. In Frifelt, K., The Island of Umm an-Nar, Vol. II, Third Millennium Settlement. The Carlsberg Foundation's Gulf Project. Jutland Archaeological Society Publications XXVI:2

Jakobsen, J.P. 1872. Arternes Oprindelse ved naturlig Selektion eller ved de heldigst stillede Formers Sejr i Kampen for Tilverelsen (oversat fra 5. udg. af Darwins On the Origin of Species ...)

Koliadin, V. 1994. «Wrong» ideas. Nature 367, 406 McKenna, M.C. 1975. Toward a phylogenetic classification of the Mammalia. In W.P. Luckett \& F.S. Szalay (eds), Phylogeny of the Primates, Plenum Press, New York, 21-46

Nielsen, J. Steen 1994. Derfor fordi. Dagbladet Information, 12.-13. februar, 21

Nisbet, E.G., Mattey, D.P. \& Lowry, D. 1994. Can diamonds be dead bacteria? Nature 367, 694

Outram, D. 1979. The Letters of Georges Cuvier. A summary calendar of manuscript and printed materials preserved in Europe, the United States of America, and Australasia. The British Society for the History of Science Monographs 2, University of Lancaster, England

Pellegrin, P. 1992. Georges Cuvier: Recherches sur les ossements fossiles de quadrupèdes. Discours préliminaire (1812). - Présentation, Flammarion, Paris

Poe, E. A. 1845. Sonnet - To Science. The Broadway Journal. In D. Galloway (ed.) 1986,
Edgar Allan Poe. The Fall of the House of Usher and Other Writings. Poems, Tales, Essays and Reviews, Penguin Books

Romm, J. 1994. A new forerunner for continental drift. Nature 367, 407-408

Scherz, G. 1969. STENO. Geological papers, Odense University Press

Stenonis, N. (Steno) 1669. De solido intra solidum naturaliter contento Dissertationis Prodromus, Florentiae (Firenze) (2. udgave publiceret $\mathrm{i}$ Amsterdam, 1679. Dansk oversættelse ved A. Krogh \& V. Maar, 1902. Forelobig Meddelelse til en Afhandling om faste Legemer, der findes naturlig indlejrede $i$ andre faste Legemer, København)

Stensen, N. (Steno) 1659. Niels Stensen. En dansk student $i 1659$ og noterne $i$ hans Chaos-manuskript ved H.D. Schepelern, 1986. Nicolaus Steno Gildet, København

Taquet, P. (under trykning). Les liens scientifiques européens de Georges Cuvier. Actes du symposium ..., Montbéliard

Tarkowskij, A. 1984. Die versiegelte Zeit. Gedanken zur Kunst, zur Ästhetik und Poetik des Films, Ullstein

Vries, S. von 1679. Neueste Beschreibung von Alt und Neu Groen-Land, Nürnberg/ in Verlegung Christof Riegels

NOTE

* "Man troede på den tid [1899], at den vestlige civilisation, forsumpet $\mathrm{i}$ rationalisme og ateisme, havde udspillet sin rolle og nu gik sit endeligt i møde». Fra "Présentation» i bogen "Rilke, Pasternak, Tsvétaïeva - Correspondance à trois Été 1926», Du monde entier, Gallimard, 1993.

Ella Hoch er vertebratpalaontolog ved Geologisk Museum (Kobenhavns Universitet).

Adr: Geologisk Museum, Øster Voldgade 5-7, DK-1350 Kobenhavn, Danmark 